\title{
Transport of light nonaqueous phase liquid in a saturated
}

\section{nonhomogeneous Soil}

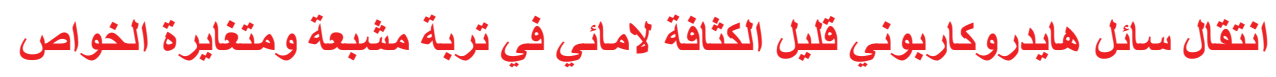

Hussein H. E. Al-Husseini ${ }^{*}$, Abbas H. Sulaymon ${ }^{* *}$, Adel O. Shareef ${ }^{* * *}$

${ }^{*}$ College. of eng.-Univ. of Babylon, ${ }^{* *}$ Islamic University Kufa, ${ }^{* * *}$ College. Of eng.-Univ. of Surry

Corresponding Author Email: Husseinihhe@gmail.com

\section{$\underline{\text { Abstract }}$}

The purpose of the present research is to study the dissolution and transport of LNAPL (toluene) from a circular pool in heterogeneous sand soil. An aquifer was constructed to conduct this aim with dimension of $(100 * 50 * 30) \mathrm{cm}$. The aquifer was packed with heterogeneous sand soil. Eight points at three depths along the aquifer were selected for sampling procedures. Samples were analysis for toluene concentration using gas chromatography devise. Three velocities of five were selected to explain the transport phenomena. Statistical analysis was applied to the data to find the correlation between measured concentrations. It was found that, the concentrations of toluene were fluctuated in the low and max porous medium flow velocities $(0.408$ and 5.118$) \mathrm{cm} /$ day effect of flow through porous media on. The statistical analysis showed that there a correlation between concentrations of toluene in the vertical direction (depth) of the medium.

Key words: LNAPL, toluene, porous media.

$$
\begin{aligned}
& \text { الخلاصة } \\
& \text { ان الهفف من الدراسة الحالية دراسة ذوبان وانتقال مركب منفرد من المواد الهيدروكاربونية الأقل كثافة من ماء التلوين }
\end{aligned}
$$

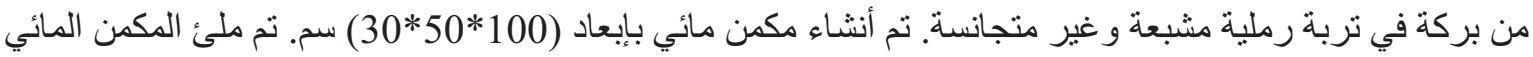

$$
\begin{aligned}
& \text { بتربة رملية غير متجانسة واختيرت ثمانية نقاط على طول المكمن و على ثلاثة اعماق تحت سطح التربة الرملية كنقاط } \\
& \text { لسحب العينات. تم تحليل العينات المسحوبة لتحديد تر اكيز التلوين باستخدام جهاز كروموتغر افي الغاز. تم التتبار ثلاث }
\end{aligned}
$$

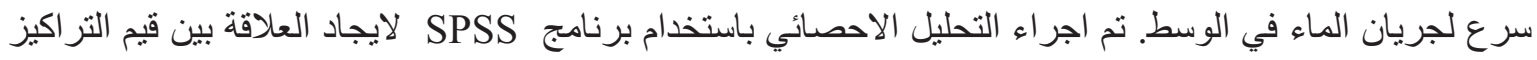

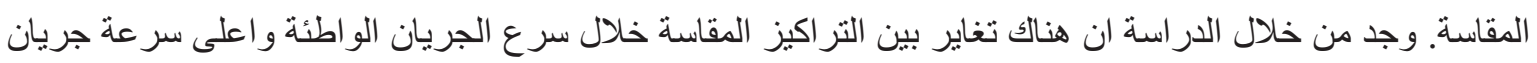

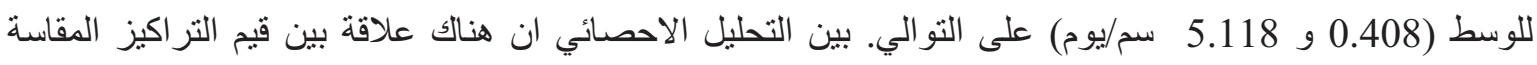

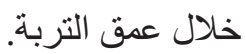




\section{Introduction}

Light nonaqueous phase liquids affect ground-water quality at many sites across the country. The most common LNAPL related ground-water contamination problems result from the release of petroleum products. These products are typically multicomponent organic mixtures composed of chemicals with varying degrees of water solubility. Some additives (e.g., methyl tertiary-butyl ether and alcohols) are highly soluble. Other components (e.g., benzene, toluene, ethyl benzene, and xylenes) are slightly soluble. [1]

Field experiences illustrating incompatibility problems of common wastes are also included. This will assist monitoring and recovery system design personnel with the decision making process concerning the most effective materials to be used in heavily contaminated subsurface environments. [2]

\section{Nonaqueous Phase Liquids}

A microbial consortium acclimatized with benzene, toluene and xylene (BTX) to study the degradation pattern of these compounds individually under aerobic conditions. The bio-kinetic parameters obtained under substrate versatility conditions were compared with those of a single substrate condition. Similar degradation patterns were observed for all the substrates with inhibition occurring at higher concentration $(\sim 150 \mathrm{mg} / \mathrm{L}$ for benzene and xylene, and $\sim 200 \mathrm{mg} / \mathrm{L}$ for toluene). Toluene degradation was highest, followed by benzene and xylene in the aqueous phase. Adaptation to a more toxic compound like benzene and xylene improved the utilization of toluene. [3]

\section{Hrterogeneous Soil}

LNAPL movement near a sloping fine- over coarse-grained textural interface, forming a capillary barrier. LNAPL flow experiments were performed in a glass chamber $(50,60,1.0 \mathrm{~cm})$ using two silica sands $(12 / 20$ and 30/40 sieve sizes). Variable water saturations near the textural interface were generated by applying water uniformly to the sand surface at various flow rates. [4] 


\section{Porous Medium}

Porous medium is a solid with holes and it has preliminary remarks including apportion of space occupied by heterogeneous or multiphase matter at least one of the phases comprising this matter is not solid.

Some of the limitations while focusing on heterogeneous and field-scale problems. They conclude that media heterogeneity plays a significant role in determining the morphology of the NAPL residual distribution, and this in turn plays a significant role in determining mass transfer from the NAPL residual. [5]

LNAPL transport on the water table numerically, by accounting for residual NAPL retained by capillary forces. The model was exercised to simulate LNAPL mound formation and migration of an established mound. The results show that the ambient groundwater velocity has major effects on both the formation and migration of LNAPL mounds, although the degree of residual saturation affected only migration. Model results provide distributions of the NAPL phase and contaminated soil. The model and the solution method developed in this study can be used as a screening tool to assess the impact of NAPL contamination and to estimate remediation costs. [6]

NAPL simulator which is used to predict the behavior of benzene under fluctuating groundwater table conditions. A very good correlation was found between water saturation, capillary pressure and the location of the water table, and it was confirmed that the hysteresis phenomenon makes the saturation pressure (S-P) relations history and path dependent. A slightly modified NAPL simulator code made a good prediction of water saturation, water flow, LNAPL flow, water table and LNAPL table of the column test. [7]

a new numerical tool which models the two-dimensional contaminant transport through saturated porous media using a mesh free method called the radial point interpolation method (RPIM) with polynomial reproduction. In RPIM, an approximate solution is constructed entirely in terms of a set of nodes and no characterization of the interrelationship of the nodes is needed. An advection-dispersion equation with sorption is considered to illustrate the applicability of the RPIM. The Galerkin weak form of the governing equation is formulated using two-dimensional mesh free shape functions constructed using thin plate spline radial basis functions. [8]

the dissolution and transport process of benzene as a light non aqueous phase liquid (LNAPL) in saturated porous media. This process is studied under unidirectional flow at 
different water velocities ranging from 0.90 to $3.60 \mathrm{~cm} / \mathrm{h}$ in a three-dimensional saturated sand tank $100 \mathrm{~cm} \times 40 \mathrm{~cm} \times 35 \mathrm{~cm}$. The experimental aquifer is simulated by developing a three-dimensional finite element numerical model. This model assumes that the dissolved concentration along the LNAPL-water interface is equal to the solubility concentration. The numerical model results over predict the experimental within factor 1.6 and 2.29 at depths of $1 \mathrm{~cm}$ and $3 \mathrm{~cm}$, respectively. [9]

In the present study the dissolution and transport process of toluene and xylene as a light non aqueous phase liquids (LNAPL) in heterogeneous saturated porous media. This process is studied under flow at different water velocities ranging from 0.408 to 10.2 $\mathrm{cm} /$ day in a three-dimensional saturated sand tank $(100 \mathrm{~cm} \times 50 \mathrm{~cm} \times 40 \mathrm{~cm})$.

\section{Materials And Experimental Work}

NAPL dissolution experiments were performed in a three dimension flow cell of $1 \mathrm{~cm}$ thick Perspex plates with inner dimensions of $120 * 50 * 50 \mathrm{~cm}$, length * width * height. This cell is divided into three chambers by using two perforded partitions .These partitions were covered by cloths to prevent the movement of the sand first and the third chambers. The cell was covered by a plate of same material and drilled at specified points for sampling well as shown in the Figure (1). The inlet and third chambers were of dimensions of $10 * 50 * 50 \mathrm{~cm}$. Inlet water chamber was connected to a constant head water tank of 20 liter which is supplied by water from the main water supply tank of 1000 liter. Outlet water chamber (third) was connected to constant head water supply tank of 5 liter which is connected to the bypass of sewage storage tank. Toluene was injected to the porous media at the position of the pool (this pool is located at the top of the sand through plastic pipe which is connected to toluene degreed glass container. The discharge of toluene was about $5.2 \mathrm{ml} / \mathrm{hr}$. Water samples were taken from eight wells positioned at centerline of the aquifer (where the depth of water above the sand surface about $1 \mathrm{~cm}$ ) at depths of 1,2 and $3 \mathrm{~cm}$ under the sand surface. 


\subsection{Materials}

\subsubsection{Porous media}

Middle chamber of Perspex cell $100 * 50 * 50 \mathrm{~cm}$ was packed with Karbala sand (heterogeneous porous media) to $30 \mathrm{~cm}$ height. Samples were tested for sand porosity and were found to be 0.394 . The permeability of the heterogeneous soil was varied with position for this purpose stochastic analysis was required for the determination of the permeability of the heterogeneous sand soil. For this purpose five points were selected at different locations through the porous media $1010-15,255-10,4015-10,5515-5,65$ $35-15$ for $\mathrm{x}$ y z coordinates respectively. At each point a sample of sand was taken and the permeability test was applied. The values of permeability of the corresponding above locations were found to be $7.952 * 10^{-3}, 6.903 * 10^{-3}, 5.44 * 10^{-3}, 7.467 *$ $10^{-3}, 7.229 * 10^{-3} \mathrm{~cm} / \mathrm{sec}$.

\subsubsection{Toluene}

Light non aqueous phase liquids used in the present study were toluene and xylene .The chemical properties of the liquids are shown in table (1).

Table (1) Chemical properties of toluene (Watts, 1997)

\begin{tabular}{|l|l|l|l|l|l|}
\hline Material & $\begin{array}{l}\text { Density } \\
(\mathrm{g} / \mathrm{cm} 3)\end{array}$ & $\begin{array}{l}\text { Dynamic } \\
\text { Viscosity } \\
(\mathrm{cp})\end{array}$ & $\begin{array}{l}\text { Water } \\
\text { Solubility } \\
(\mathrm{mg} / \mathrm{l})\end{array}$ & $\begin{array}{l}\text { Vapor } \\
\text { Pressure } \\
(\mathrm{mm} \mathrm{Hg})\end{array}$ & $\begin{array}{l}\text { Henry's Law } \\
\text { Constant } \\
(\mathrm{atm}-\mathrm{m} 3 / \mathrm{mol})\end{array}$ \\
\hline Toluene & 0.8669 & 0.58 & 546 & 22 & $6.61 \mathrm{E}-03$ \\
\hline
\end{tabular}

\subsection{Experimental work}

\subsubsection{Permeability test}

The constant head permeability test was used to determine the permeability of the soil. The coefficient of permeability can be computed from

$$
k=\frac{Q L}{t h A}
$$

Where

$k=$ permeability coefficient $(\mathrm{cm} / \mathrm{sec}), Q=$ flow rate through the soil in elapsed time $t$ (ml/sec), $h=$ the total head lost $(\mathrm{cm}), A=$ area of the soil sample $\left(\mathrm{cm}^{2}\right), L=$ length of the soil sample $(\mathrm{cm})$. 


\subsubsection{Velocity test}

The velocity of the water flow through a porous media effected by the heterogeneity of the soil, while not vary with homogeneous media. The degree of heterogeneity of the media limited the range of velocities that may be achieved through it. The velocity test was achieved by using water flow only through the aquifer. The test was included the determination of the maximum velocity possible in the sand media with constant head through aquifer, this was carried out by increasing the velocity of water gradually using flow meter to the moment at which the constant head was changed with time along the aquifer. This velocity represents the maximum allowable velocity in a specified aquifer, and it was found to be10.2 cm/day. Different water velocities $5.118,0.408 \mathrm{~cm} /$ day were selected from five values of velocity were used.

\subsubsection{Sampling and analysis}

Water was the main liquid flowing through porous media .This water was supplied from a constant head water tank, Figure (1). Water flowing through the porous medium was controlled using steel ball valves and flow meter type (Eau Wasser). The level of water above the surface sand was controlled to be constant about $1 \mathrm{~cm}$. This was achieved by carried out an experiment to let the water flowing through aquifer and at the same time the elevation of the constant head water supply of volume 5 liter was fixed at water level above surface sand at $1 \mathrm{~cm}$. 


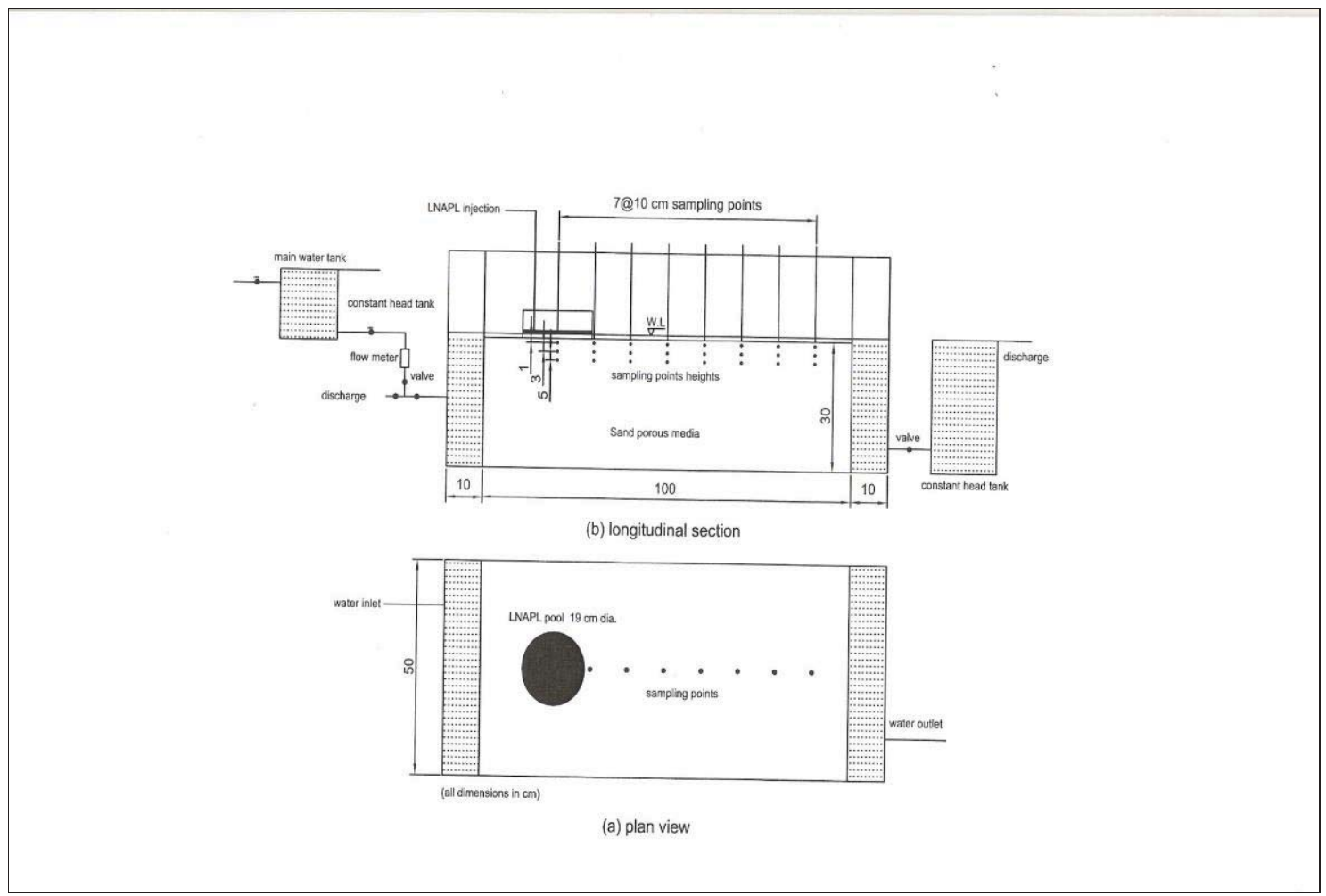

Fig. (1) Aquifer sand apparatus

\section{STATISTICAL ANALYSIS}

Statistical analysis was applied to the experimental data. SPSS program was used to calculate the correlation parameters. The analysis was applied to the concentrations in the horizontal and vertical lines of the porous media. Best representation of experimental data was drawn using best polynomial curves with high correlation factor.

\section{RESULT and DISSCUSSION}

The variations of toluene concentration with time along the aquifer are shown in (Fig. 2 to Fig. 28) at depths 1, 3 and $5 \mathrm{~cm}$ under aquifer surface, respectively. Three sections were selected to show this variation in each depth for a specified velocity.

The fluctuation of the toluene concentrations was appeared in most of these figures, but it was followed that the concentrations were increased with time. The fluctuation in the concentrations of the toluene due to the nature of the soil heterogeneity this mean that the water flowing through the pore soil was not a straight line; this was effect on toluene concentrations. 
At velocity of $0.408 \mathrm{~cm} /$ day the concentrations of toluene were fluctuated between 0 to 100 $\mathrm{mg} / \mathrm{l}$ during period of test. This fluctuation may be to the dominant transverse dispersion. This process was taken in all depth of test in media (Fig. 2 to Fig. 10). When flowing velocity increased to $5.118 \mathrm{~cm} /$ day the concentration during same period take increasing orientation the velocity may be dominant to transverse dispersion of LNAPL, (Fig. 11 to Fig. 19). At maximum velocity in porous media, (102) $\mathrm{cm} /$ day. This max velocity was dominant and be water flow with this speed through continuous channels in the depths of porous media in small period. (Fig. 19 to Fig. 28).

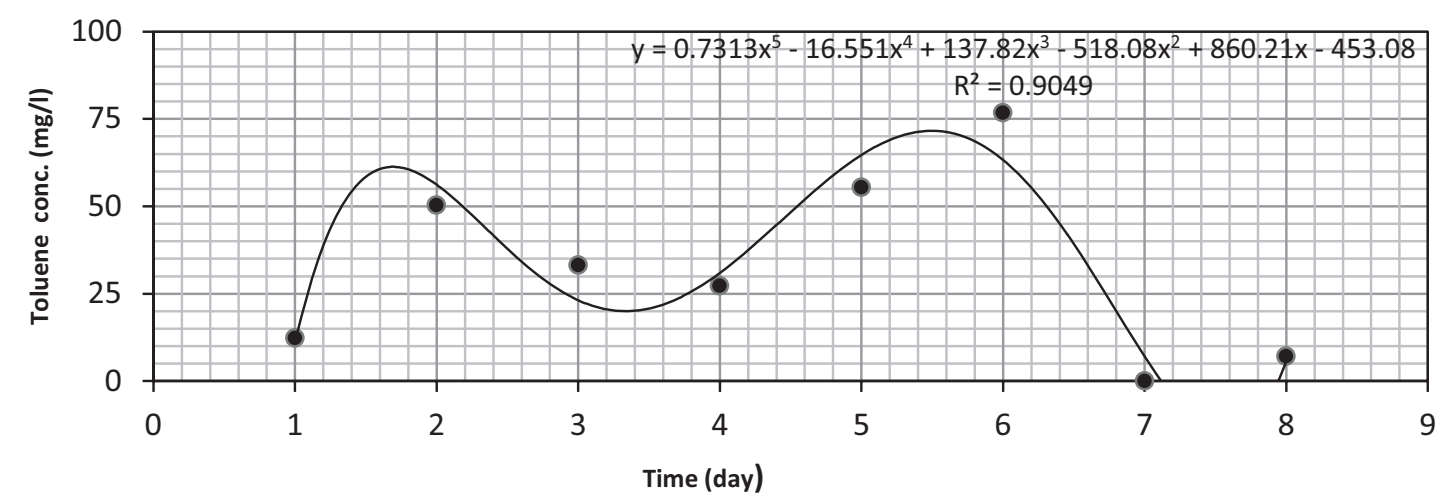

Fig. (2) Change of toluene concentration with time at section (1) at inlet velocity $0.408 \mathrm{~cm} / \mathrm{day}$ (depth $1 \mathrm{~cm})$.

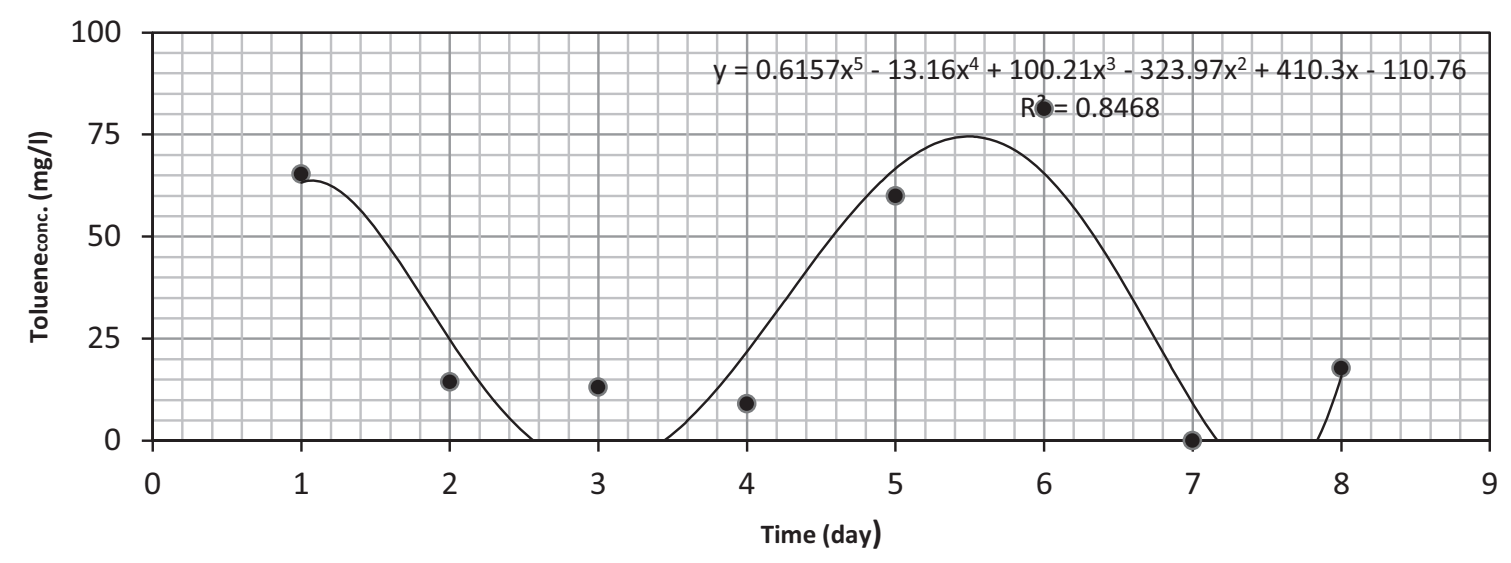

Fig. (3) Change of toluene concentration with time at section (1) at inlet velocity $0.408 \mathrm{~cm} / \mathrm{day}$ (depth $3 \mathrm{~cm})$. 


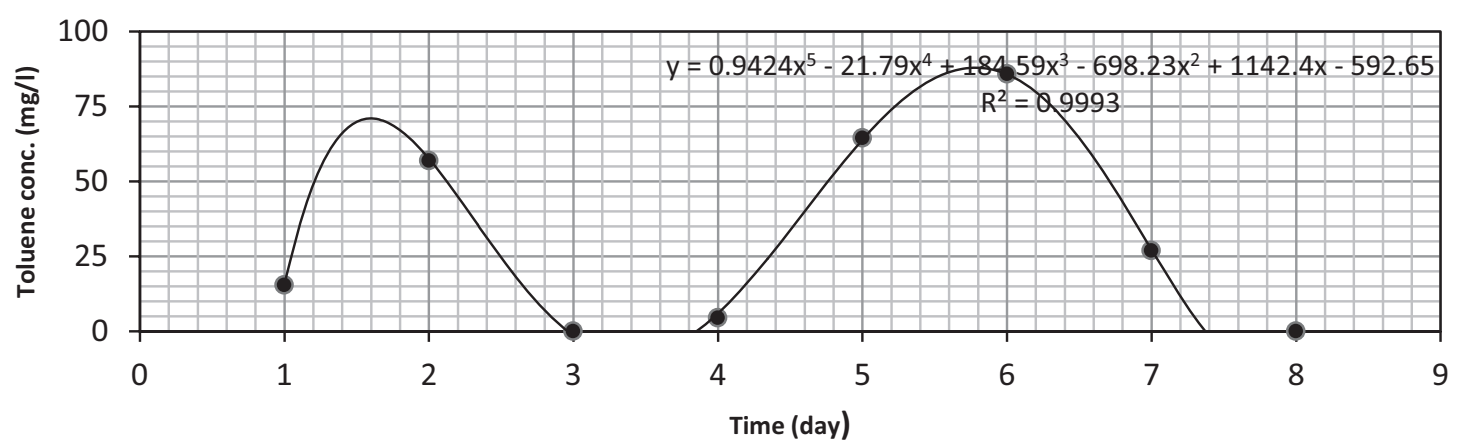

Fig. (4) Change of toluene concentration with time at section (1) at inlet velocity $0.408 \mathrm{~cm} / \mathrm{day}$ (depth $5 \mathrm{~cm})$.

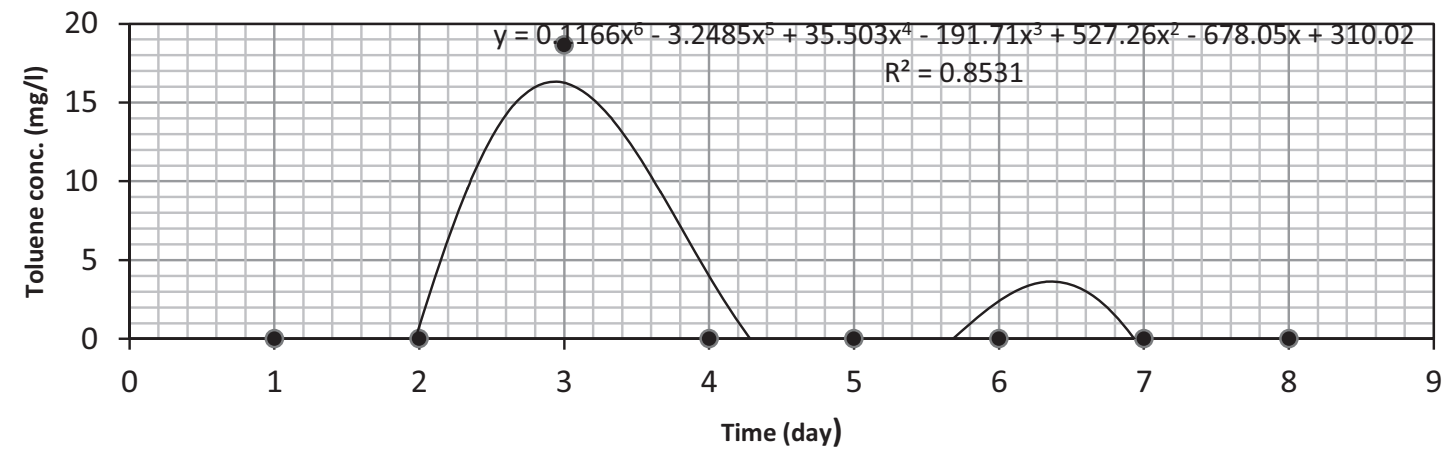

Fig. (5) Change of toluene concentration with time at section (4) at inlet velocity $0.408 \mathrm{~cm} / \mathrm{day}$ (depth $1 \mathrm{~cm})$.

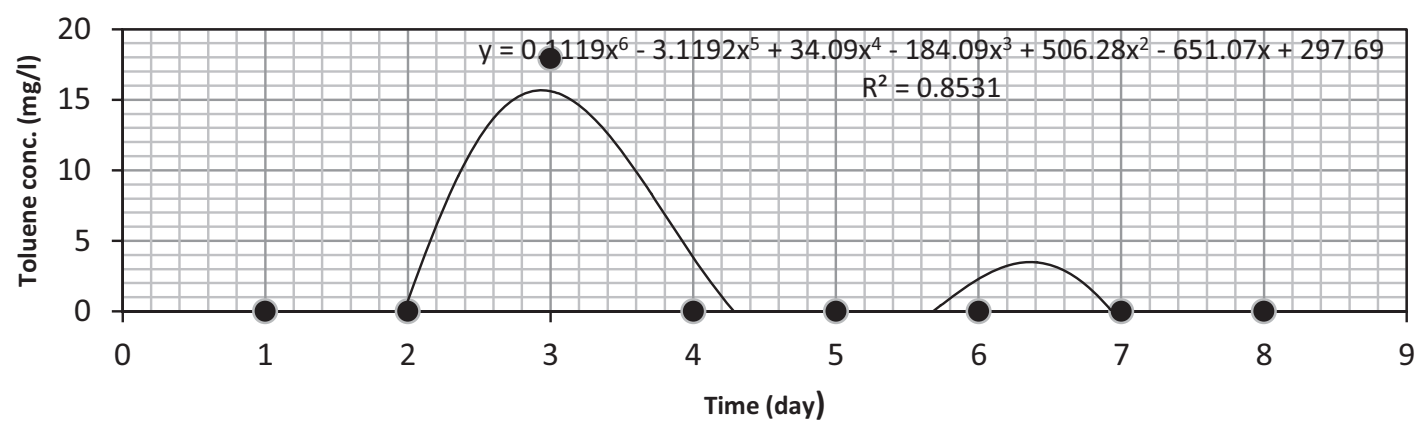

Fig. (6) Change of toluene concentration with time at section (4) at inlet velocity $0.408 \mathrm{~cm} / \mathrm{day}$ (depth $3 \mathrm{~cm}$ ). 


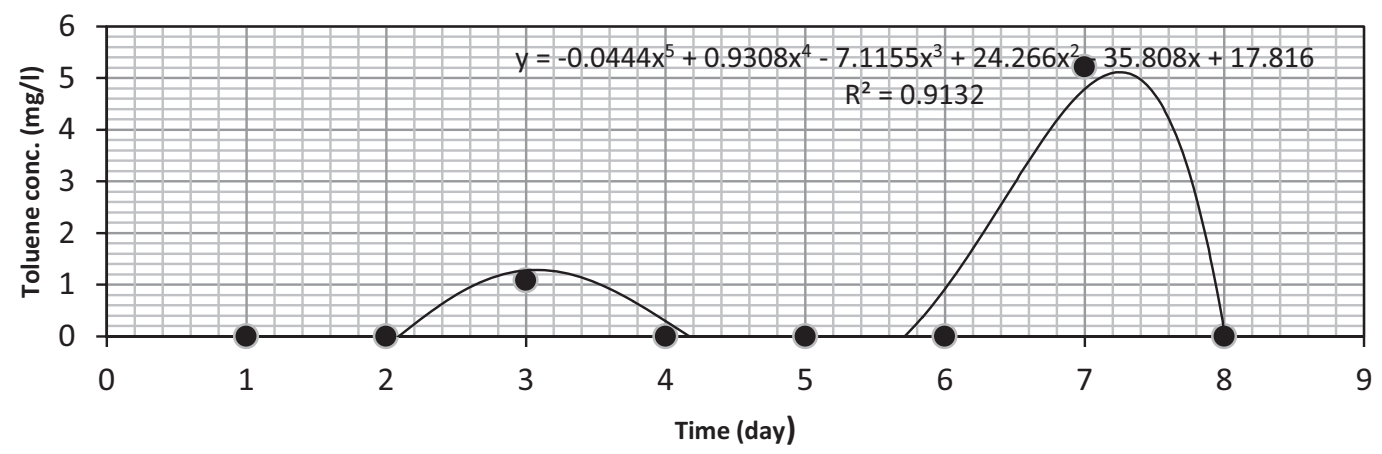

Fig. (7) Change of toluene concentration with time at section (4) at inlet velocity $0.408 \mathrm{~cm} / \mathrm{day}$ (depth $5 \mathrm{~cm})$.

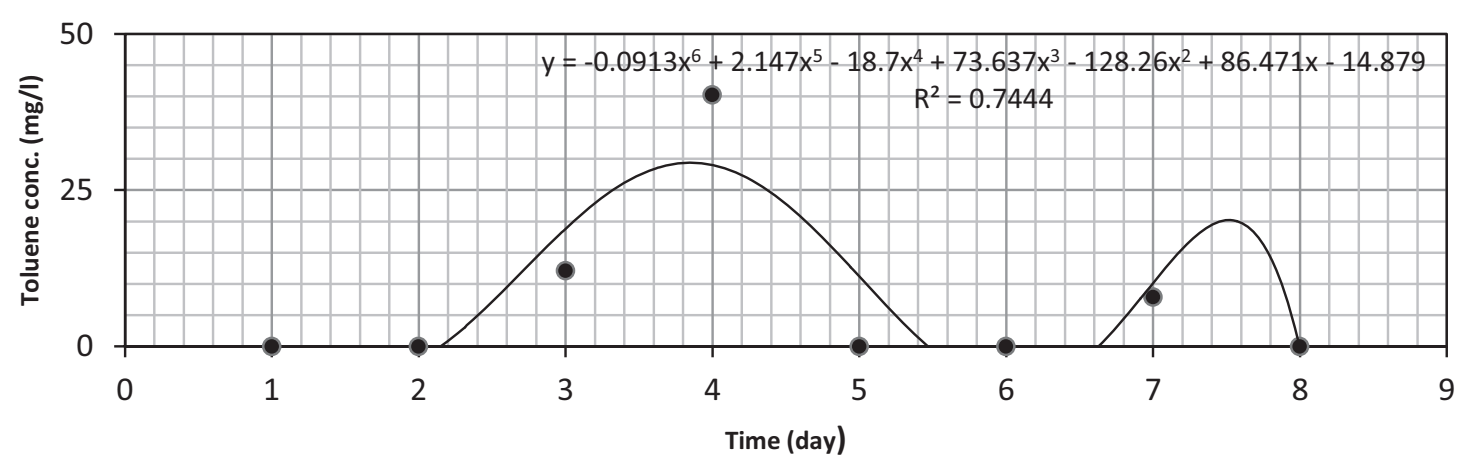

Fig. (8) Change of toluene concentration with time at section (8) at inlet velocity $0.408 \mathrm{~cm} / \mathrm{day}$ (depth $1 \mathrm{~cm})$.

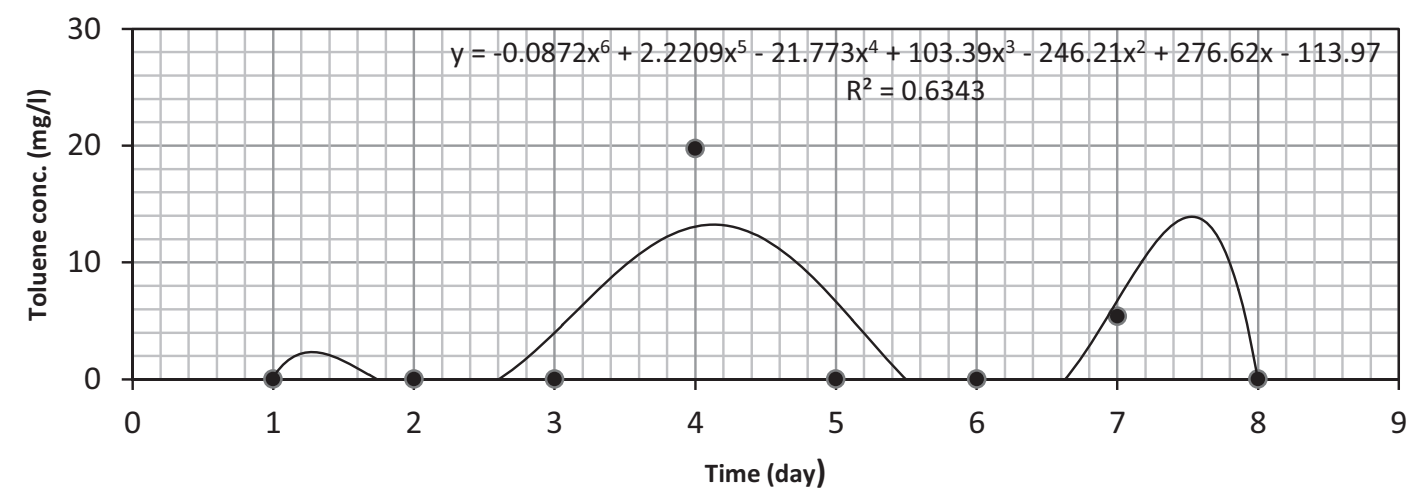

Fig. (9) Change of toluene concentration with time at section (8) at inlet velocity $0.408 \mathrm{~cm} / \mathrm{day}$ (depth $3 \mathrm{~cm}$ ). 


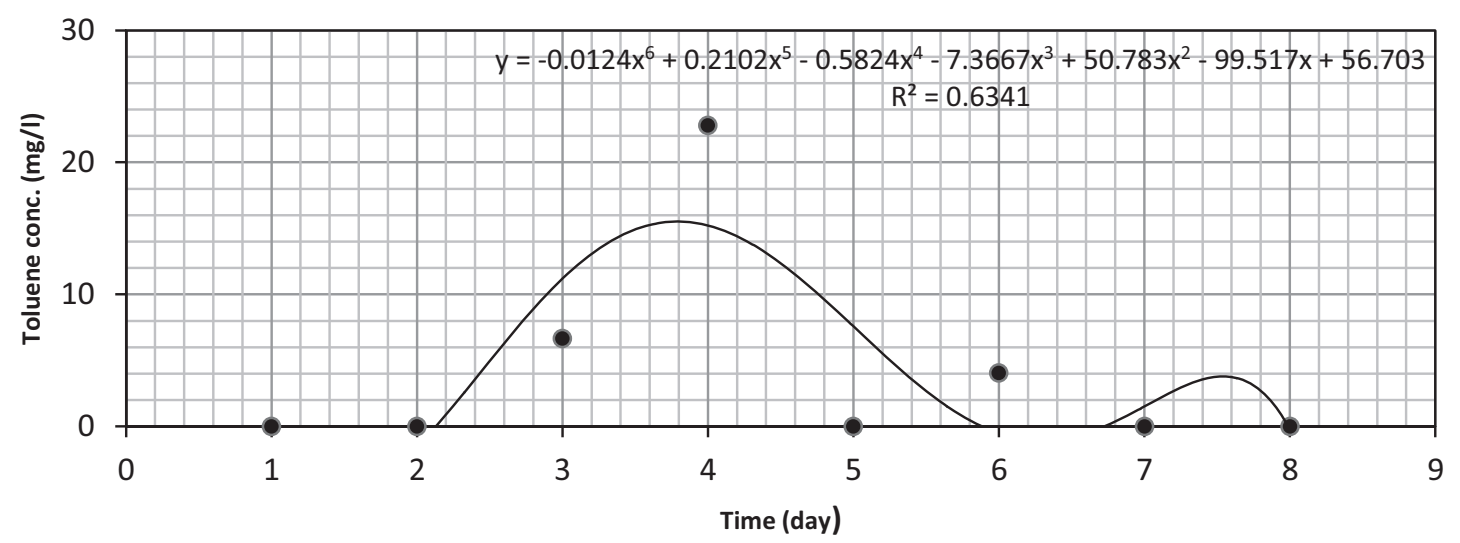

Fig. (10) Change of toluene concentration with time at section (8) at inlet velocity $0.408 \mathrm{~cm} / \mathrm{day}$ (depth $5 \mathrm{~cm})$.

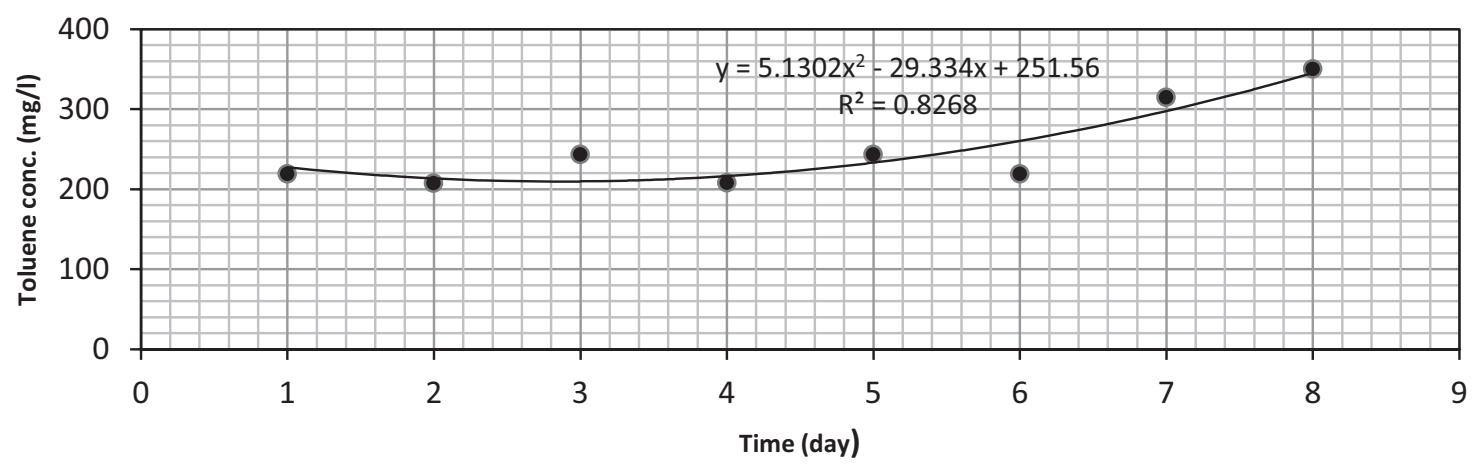

Fig. (11) Change of toluene concentration with time at section (1) at inlet velocity $5.118 \mathrm{~cm} / \mathrm{hr}$ (depth $1 \mathrm{~cm})$.

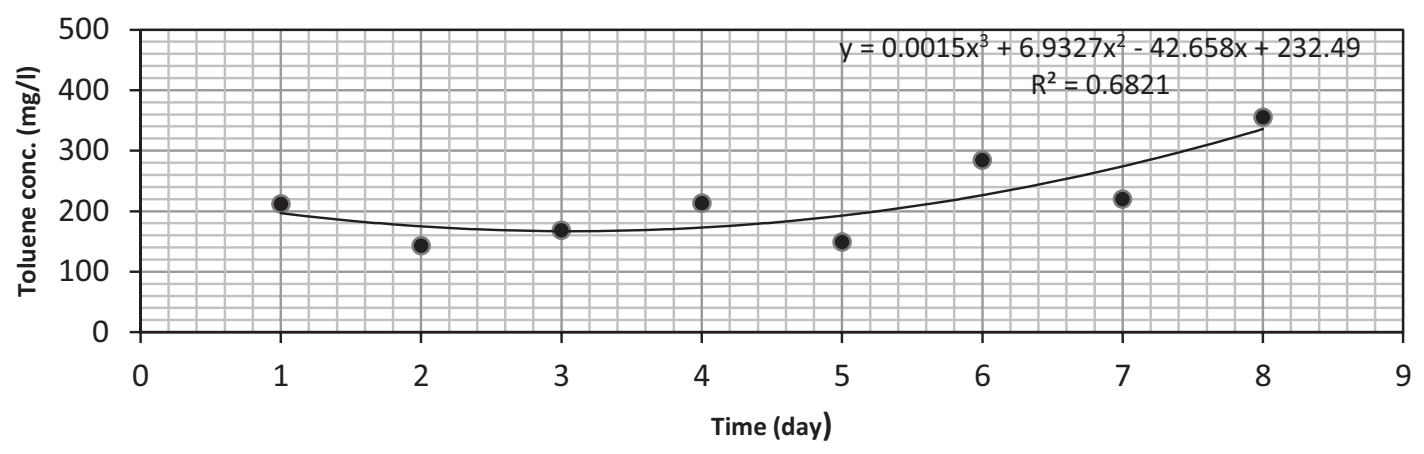

Fig. (12) Change of toluene concentration with time at section (1) at inlet velocity $5.118 \mathrm{~cm} / \mathrm{day}$ (depth $3 \mathrm{~cm})$. 


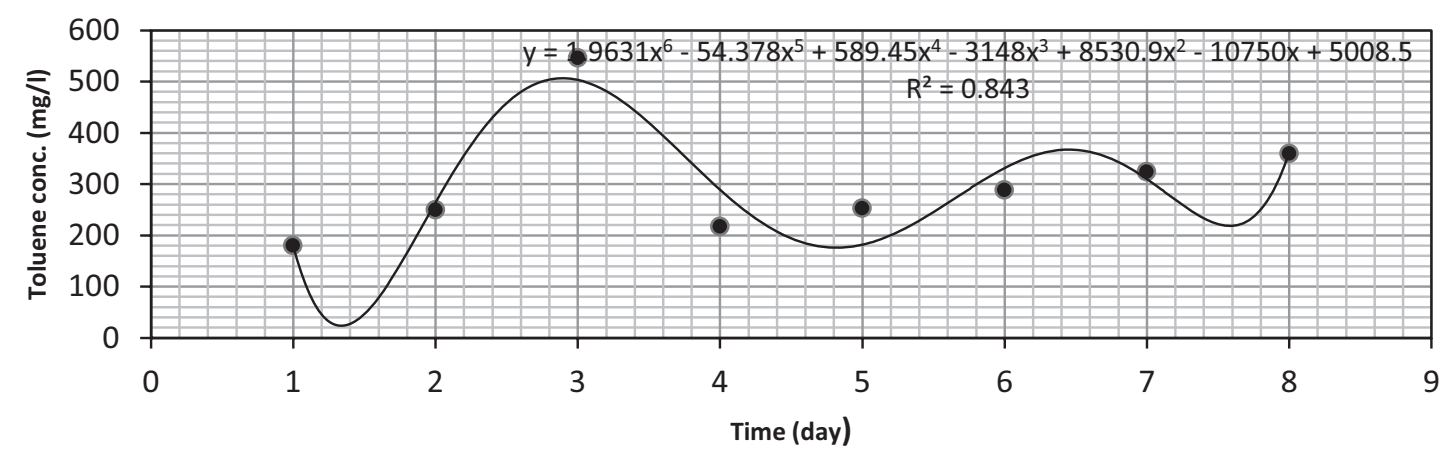

Fig. (13) Change of toluene concentration with time at section (1) at inlet velocity $5.118 \mathrm{~cm} / \mathrm{day}$ (depth $5 \mathrm{~cm})$.

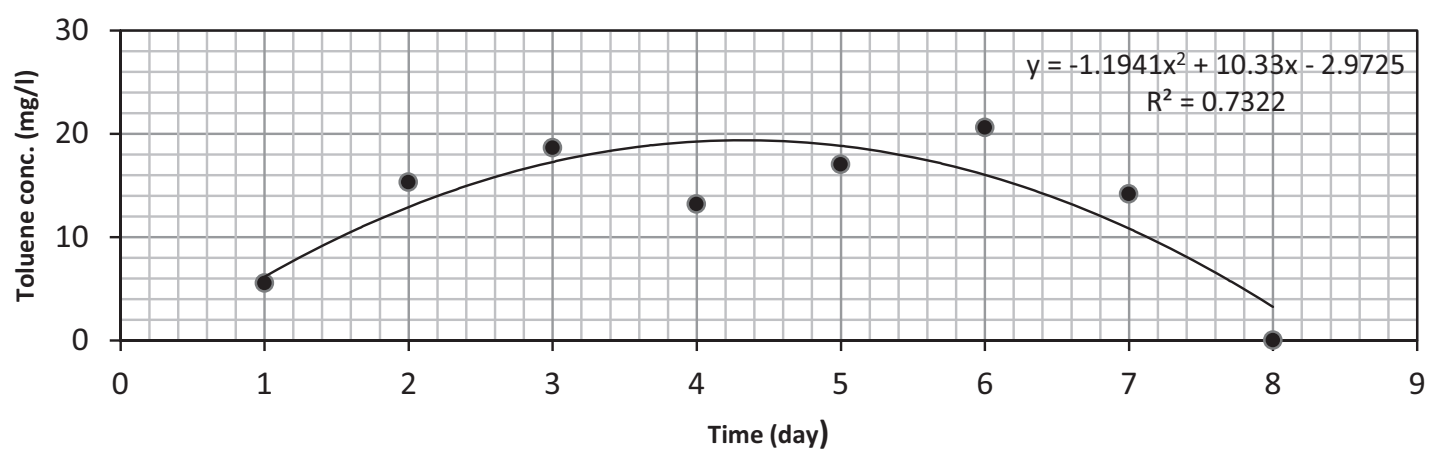

Fig. (14) Change of toluene concentration with time at section (4) at inlet velocity $5.118 \mathrm{~cm} / \mathrm{day}$ (depth $1 \mathrm{~cm})$.

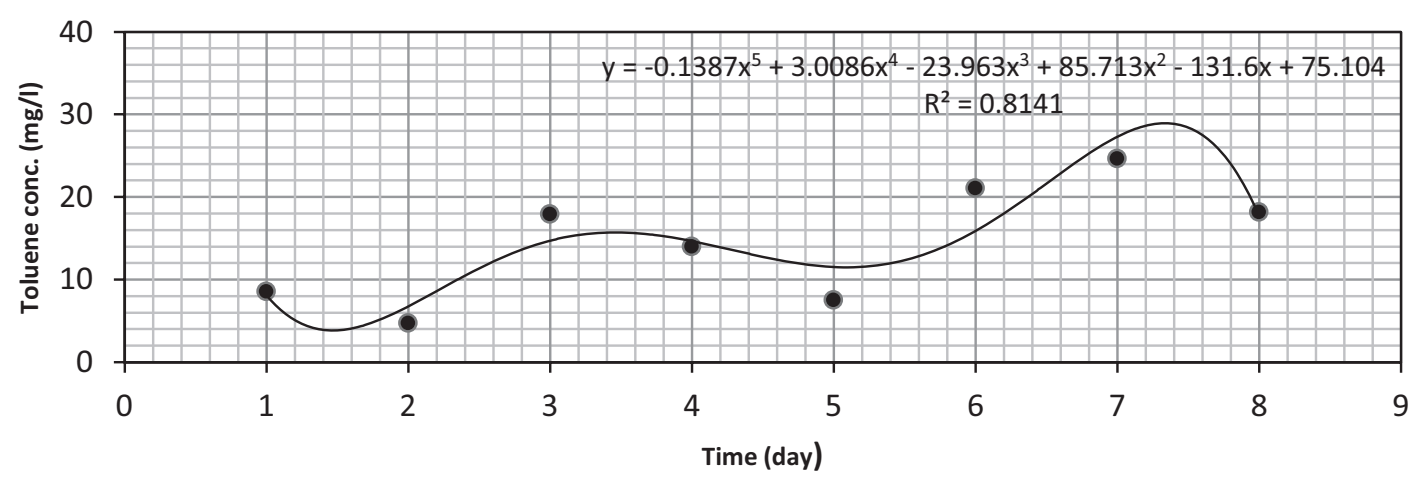

Fig. (15) Change of toluene concentration with time at section (4) at inlet velocity $5.118 \mathrm{~cm} / \mathrm{day}$ (depth $3 \mathrm{~cm})$. 


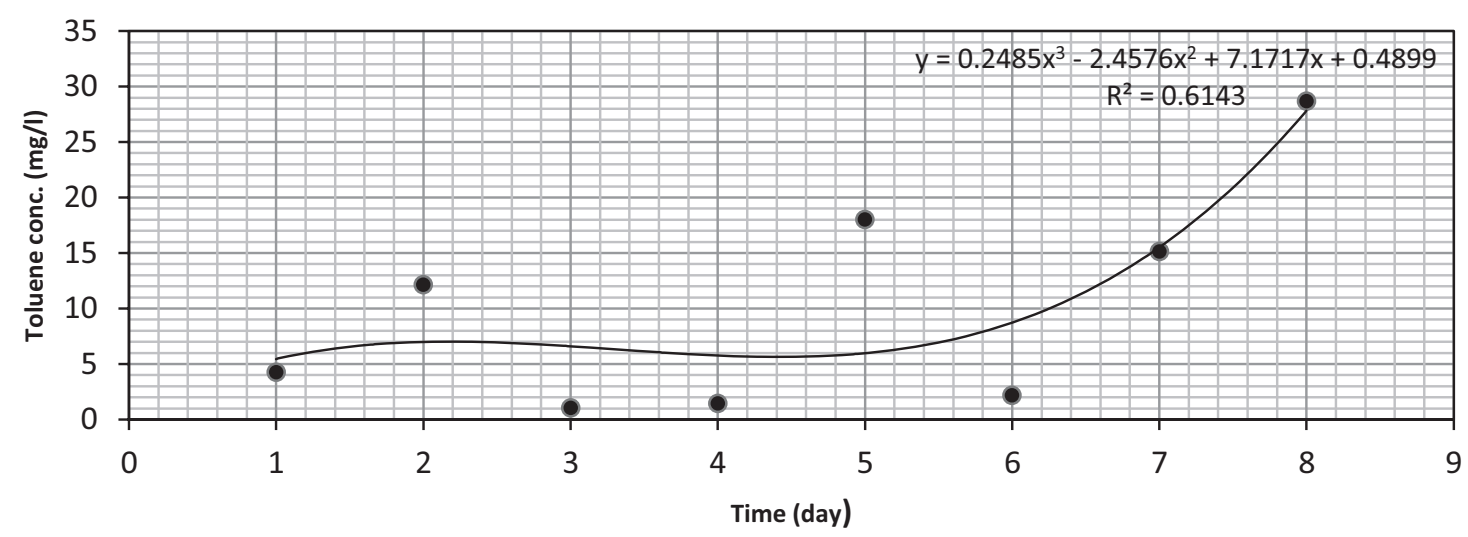

Fig. (16) Change of toluene concentration with time at section (4) at inlet velocity $5.118 \mathrm{~cm} / \mathrm{day}$ (depth $5 \mathrm{~cm}$ ).

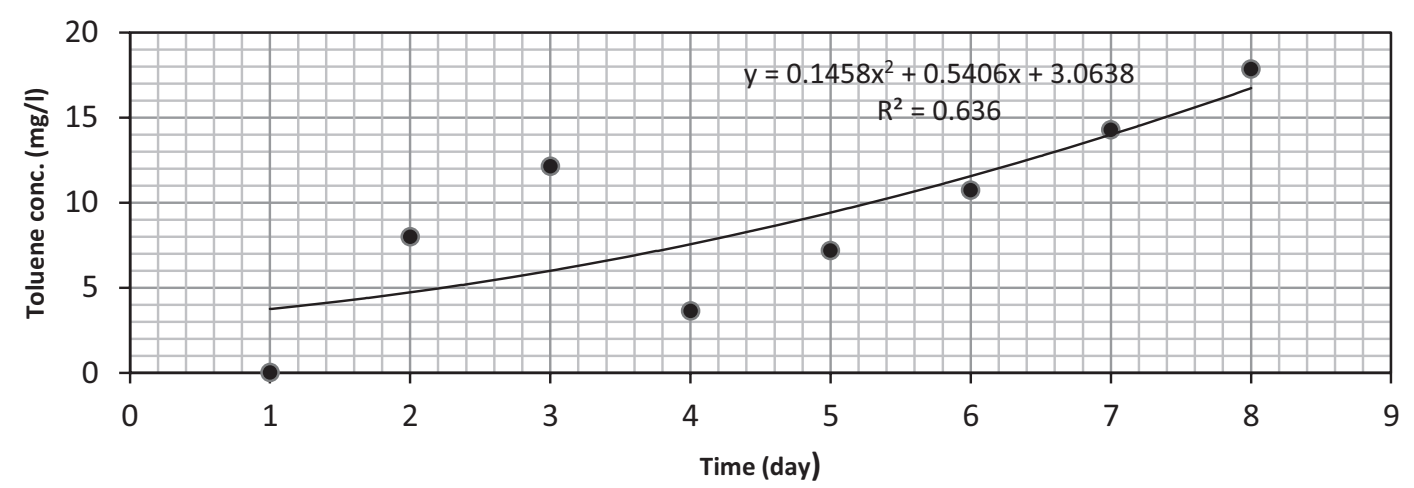

Fig. (17) Change of toluene concentration with time at section (8) at inlet velocity $5.118 \mathrm{~cm} / \mathrm{day}$ (depth $1 \mathrm{~cm})$.

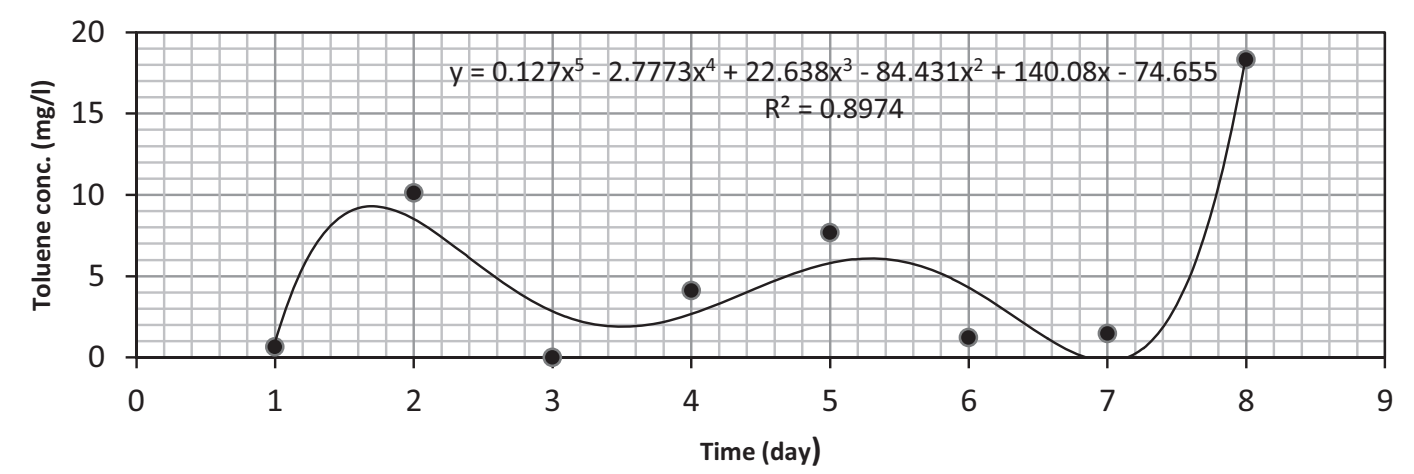

Fig. (18) Change of toluene concentration with time at section (8) at inlet velocity $5.118 \mathrm{~cm} / \mathrm{day}$ (depth $3 \mathrm{~cm})$. 


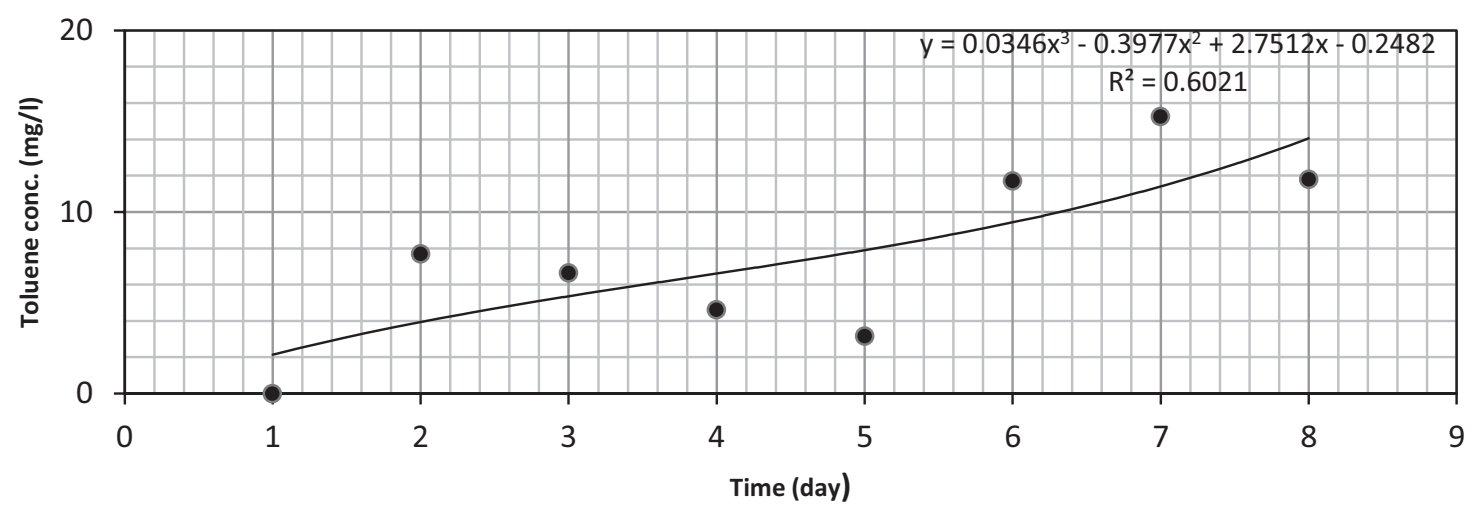

Fig. (19) Change of toluene concentration with time at section (8) at inlet velocity $5.118 \mathrm{~cm} / \mathrm{day}$ (depth $5 \mathrm{~cm})$.

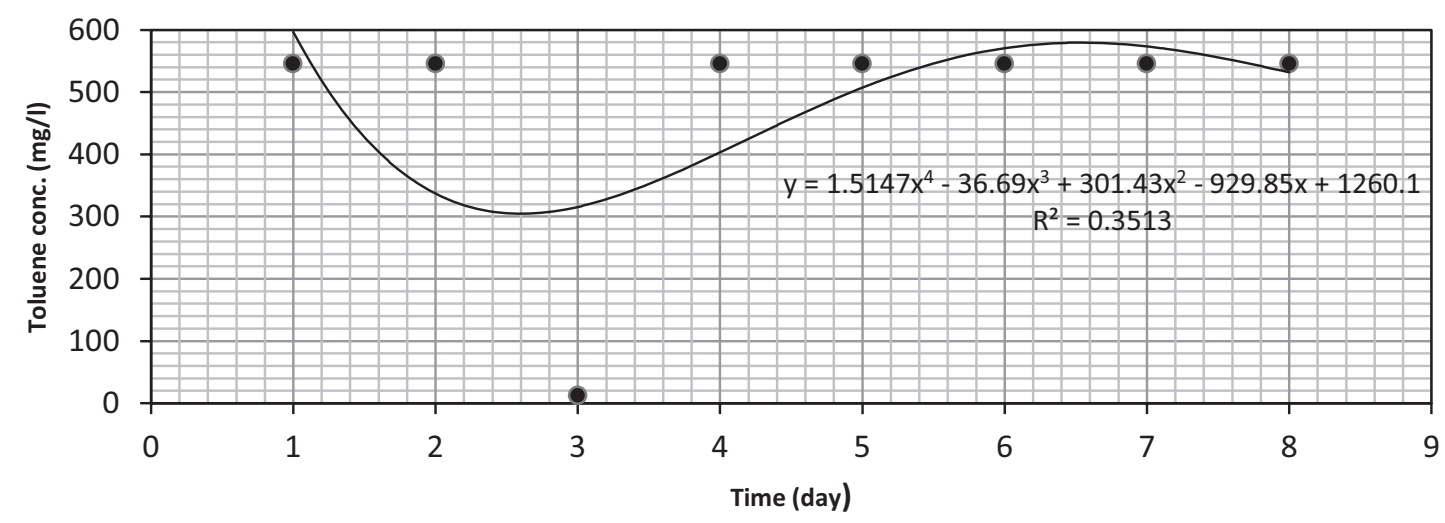

Fig. (20) Change of toluene concentration with time at section (1) at inlet velocity $10.2 \mathrm{~cm} / \mathrm{day}$ (depth $1 \mathrm{~cm})$.

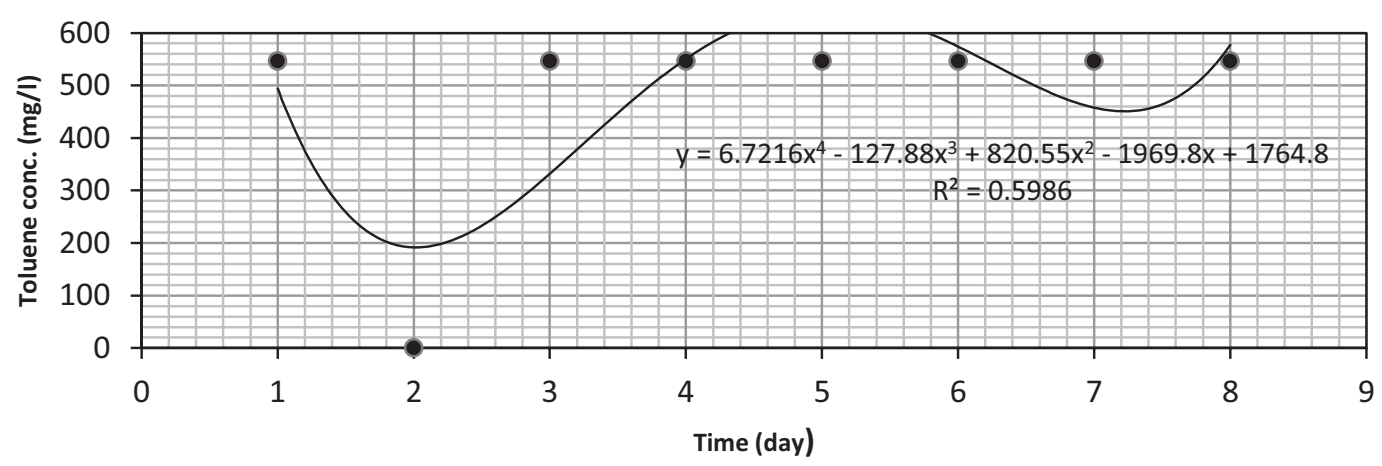

Fig. (21) Change of toluene concentration with time at section (1) at inlet velocity $10.2 \mathrm{~cm} / \mathrm{day}$ (depth $3 \mathrm{~cm})$. 


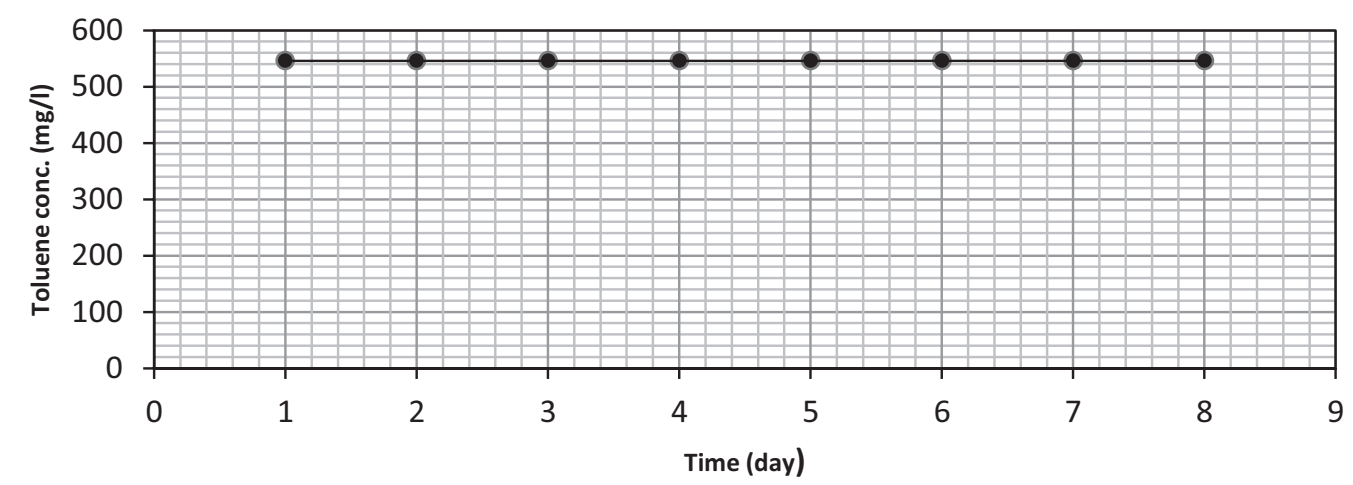

Fig. (22) Change of toluene concentration with time at section (1) at inlet velocity $10.2 \mathrm{~cm} / \mathrm{day}$ (depth $5 \mathrm{~cm})$.

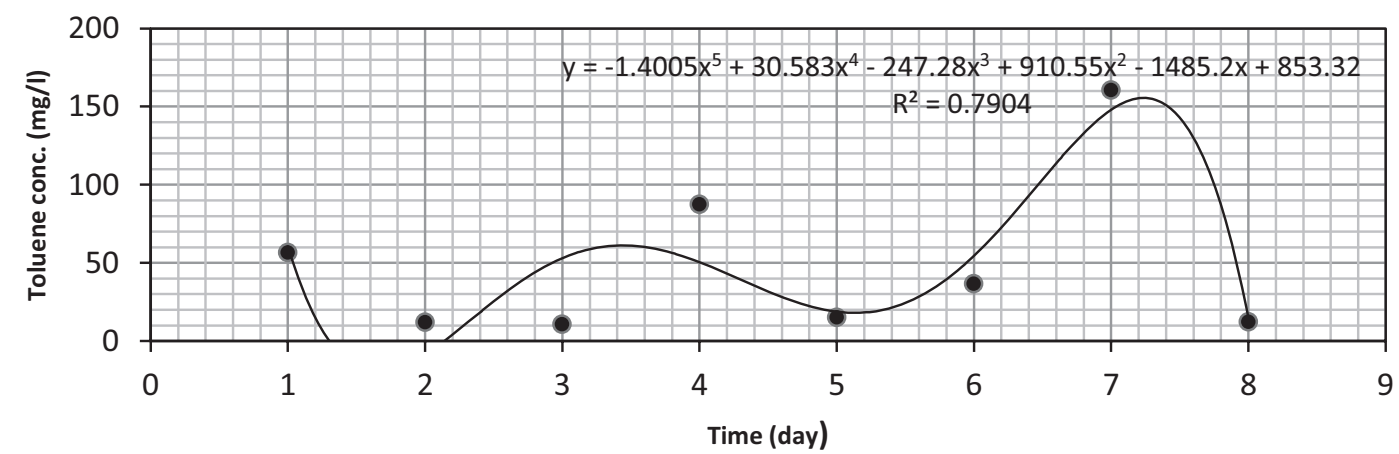

Fig. (23) Change of toluene concentration with time at section (4) at inlet velocity $10.2 \mathrm{~cm} / \mathrm{day}$ (depth $1 \mathrm{~cm})$.

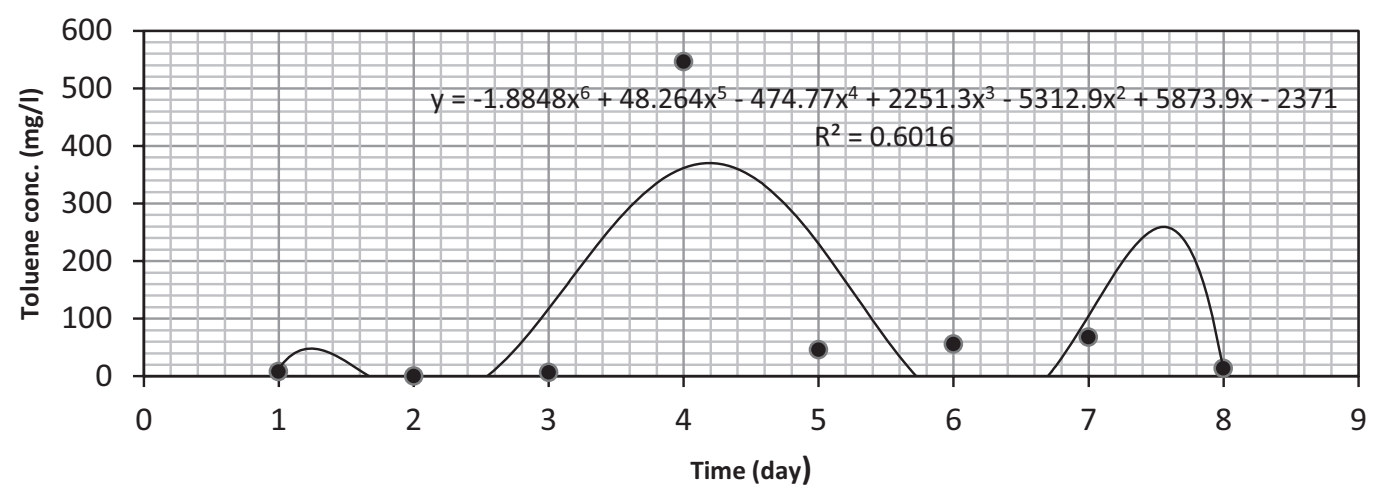

Fig. (24) Change of toluene concentration with time at section (4) at inlet velocity $10.2 \mathrm{~cm} / \mathrm{day}$ (depth $3 \mathrm{~cm}$ ). 


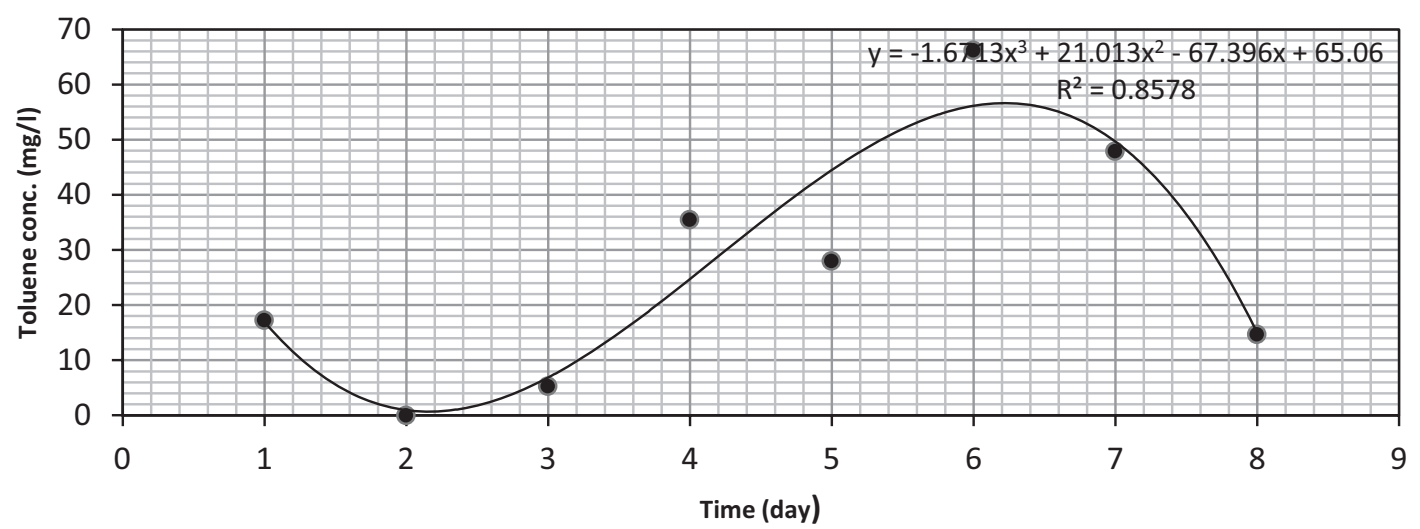

Fig. (25) Change of toluene concentration with time at section (4) at inlet velocity $10.2 \mathrm{~cm} / \mathrm{day}$ (depth $5 \mathrm{~cm})$.

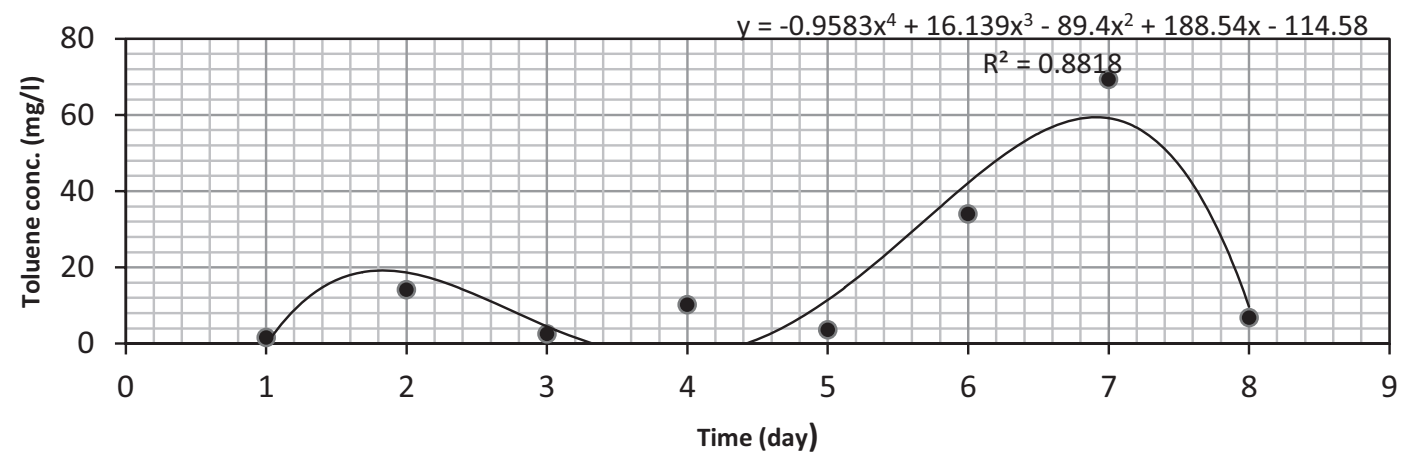

Fig. (26) Change of toluene concentration with time at section (8) at inlet velocity $10.2 \mathrm{~cm} / \mathrm{day}$ (depth $1 \mathrm{~cm})$.

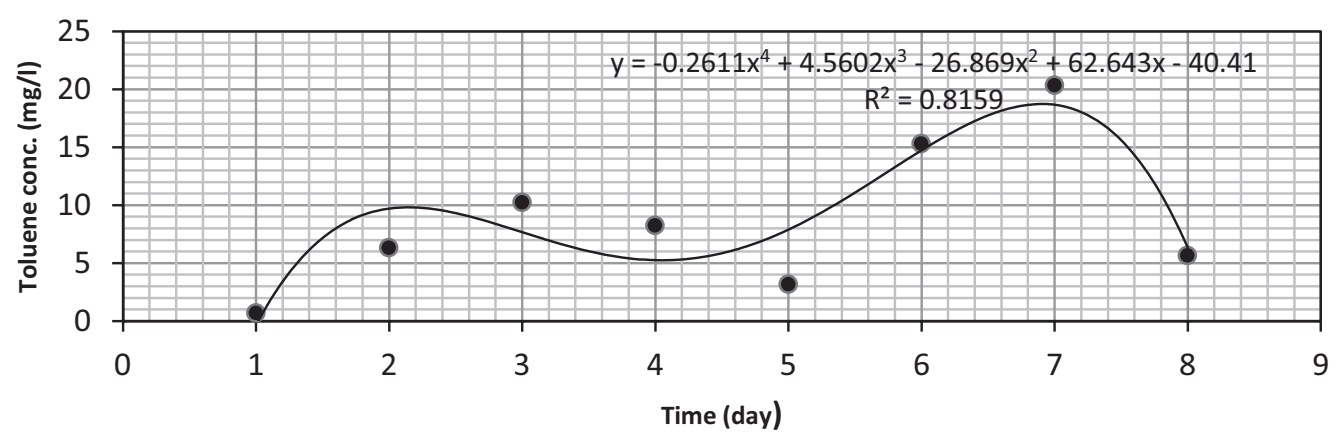

Fig. (27) Change of toluene concentration with time at section (8) at inlet velocity $10.2 \mathrm{~cm} / \mathrm{day}$ (depth $3 \mathrm{~cm}$ ). 


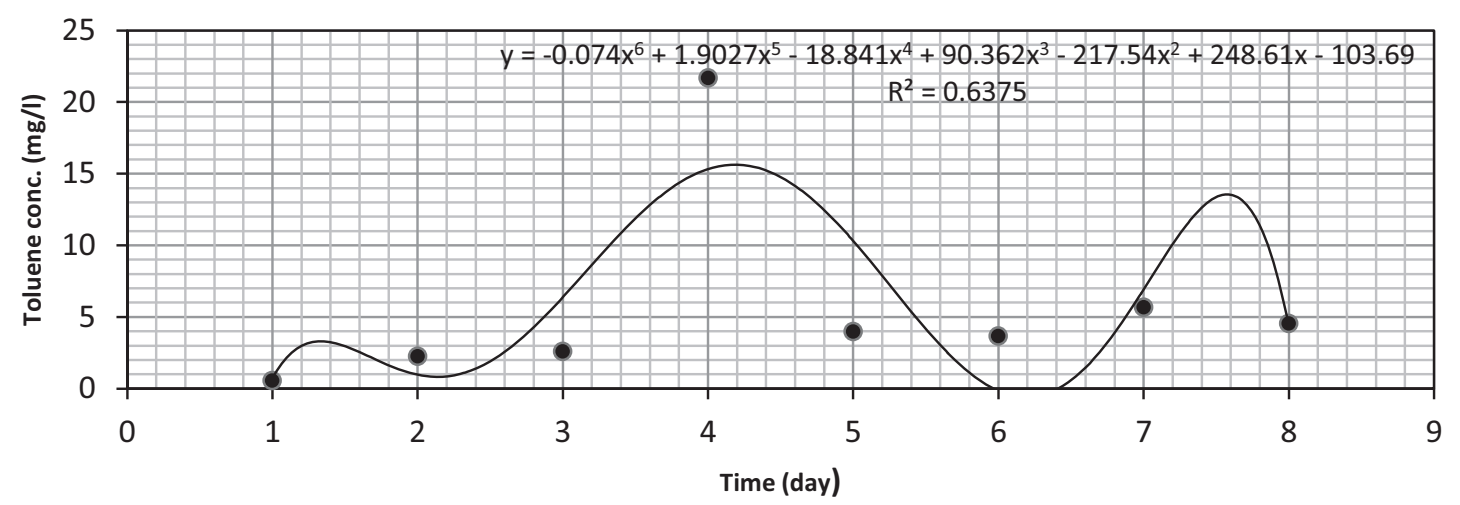

Fig. (28) Change of toluene concentration with time at section (8) at inlet velocity $10.2 \mathrm{~cm} / \mathrm{day}$ (depth $5 \mathrm{~cm})$.

The correlation matrix of the data is shown in table (1). The correlation parameters represented the relation between points of sampling along the horizontal and vertical lines of aquifer. As shown in the table, there is no or low correlation between concentrations in the horizontal line in the aquifer. There is high correlation between concentrations in the vertical line of aquifer. High correlation between vertical points was found in section one and eight. This is due to the previous discussion of movement of toluene dissolved in water in porous media.

Table (1) Correlation Matrix of Experimental Data

\begin{tabular}{|c|c|c|c|c|c|c|c|c|c|}
\hline & \multicolumn{3}{|c}{ Depths of Section 1 } & \multicolumn{3}{c|}{ Depths of Section 2 } & \multicolumn{2}{c|}{ Depths of Section 3 } \\
\hline days & $\mathbf{1} \mathbf{~ c m ~}$ & $\mathbf{3} \mathbf{~ c m}$ & $\mathbf{5} \mathbf{~ c m}$ & $\mathbf{1} \mathbf{~ c m}$ & $\mathbf{3} \mathbf{~ c m}$ & $\mathbf{5} \mathbf{~ c m}$ & $\mathbf{1} \mathbf{~ c m}$ & $\mathbf{3} \mathbf{~ c m}$ & $\mathbf{5} \mathbf{~ c m}$ \\
\hline $\mathbf{1}$ & 1 & 0.580 & 0.813 & 0.006 & 0.006 & -0.502 & -0.183 & -0.221 & 0.037 \\
\hline $\mathbf{2}$ & 0.580 & 1 & 0.616 & -0.253 & -0.253 & -0.480 & -0.474 & -0.424 & -0.273 \\
\hline $\mathbf{3}$ & 0.813 & 0.616 & 1 & -0.387 & -0.387 & -0.138 & -0.468 & -0.350 & -0.334 \\
\hline $\mathbf{4}$ & 0.006 & -0.253 & -0.387 & 1 & 1 & 0.059 & 0.133 & -0.182 & 0.125 \\
\hline $\mathbf{5}$ & -0.502 & -0.480 & -0.138 & 0.059 & 0.059 & 1 & 0.038 & 0.095 & -0.190 \\
\hline $\mathbf{6}$ & -0.183 & -0.474 & -0.468 & 0.133 & 0.133 & 0.038 & 1 & 0.950 & 0.960 \\
\hline $\mathbf{7}$ & -0.221 & -0.424 & -0.350 & -0.182 & -0.182 & 0.095 & 0.950 & 1 & 0.892 \\
\hline $\mathbf{8}$ & 0.037 & -0.273 & -0.334 & 0.125 & 0.125 & -0.190 & 0.960 & 0.892 & 1 \\
\hline
\end{tabular}




\section{No.20 Journal of Petroleum Research \& Studies}

(JPR\&S)

\section{Conclusions}

- The maximum velocity in the nonhomogeneous aquifer equal to $10.2 \mathrm{~cm} /$ day.

- At low velocity the concentration of toluene fluctuated due to transverse dispersion.

- At low velocity the concentration of toluene fluctuated due to the heterogeneity of the porous media.

- The correlations between concentrations through the depth of soil were high.

- The correlations between concentrations at middle velocity $5.118 \mathrm{~cm} /$ day were high.

- Low correlation between concentrations at low and high velocity due to dominant of transverse dispersion and heterogeneity of soil. 


\section{References}

1. Newell Charles J, Steven D. Acree, Randall R. Ross, and Scott G. Huling, 1995, "Light Nonaqueous Phase Liquids" Ground Water Issue, EPA/540/S-95.

2. McCaulou Douglas R., David G. Jewett, and Scott G. Huling, 1995, Nonaqueous Phase Liquids Compatibility with Materials Used in Well Construction, Sampling, and Remediation, Ground Water Issue EPA/540/S-95/503.

3. Maliyekkal Shihabudeen M. , Eldon R. Reneb, Ligy Philip and T. Swaminathan,2004, Performance of BTX degraders under substrate versatility conditions, Journal of Hazardous Materials B109, 201-211.

4. Schroth M. H. , J. D. Istoka, J. S. Selker, M. Oostrom \& M. D. White, 1998, Multi fluid flow in bedded porous media: laboratory experiments and numerical simulations, Advances in Water Resources Vol. 22, No. 2, 169-183.

5. Miller Cass T., Clinton S. Willson, Simon N. Gleyzer, Mattheew W. Farthing, Miller, C.T., M.M. Poirier-McNeill, and A.S. Mayer, 1998 ,Dissolution of trapped nonaqueous phase liquids: Mass transfer characteristics, Water Resour. Res., 26(11), 2783- 2796.

6. Kim Jeongkon and M. Yavuz Corapcioglu, 2001, Sharp Interface Modeling of LNAPL Spreading and Migration on the Water Table, environmental engineering science Volume 18, Number 6, Mary Ann Liebert, Inc, 359-367.

7. Kamon Masashi, Yan LI, Giancarlo Flores, Toru Inui and Takeshi Katsumi, 2006, Experimental and Numerical Study on Migration of LNAPL under the Influence of Fluctuating Water Table in Subsurface, Annuals of Disas. Prev. Res. Inst., Kyoto Univ., No. 49 B, 383-392

8. Kumar R. Praveen and G. R. Dodagoudar, 2008, Two-dimensional modeling of contaminant transport through saturated porous media using the radial point interpolation method (RPIM), Hydrogeology Journal, 1497-1505

9. Sulaymoon Abaas H. and Hatem Asal Gzar,2011, Experimental investigation and numerical modeling of light nonaqueous phase liquid dissolution and transport in a saturated zone of the soil , Journal of Hazardous Materials. Volume 186, Issues 2-3, 28 February 2011, 1601-1614. 